\begin{tabular}{|l|l|l|}
\hline \multicolumn{2}{|c|}{ PublisherInfo } \\
\hline \hline PublisherName & $:$ & BioMed Central \\
\hline \hline PublisherLocation & $:$ & London \\
\hline \hline PublisherImprintName & $:$ & BioMed Central \\
\hline \hline
\end{tabular}

\title{
Anthrax genome sequenced
}

\begin{tabular}{|l|l|l||}
\hline \multicolumn{2}{|c|}{ ArticleInfo } \\
\hline \hline ArticleID & $:$ & 4764 \\
\hline \hline ArticleDOI & $:$ & $10.1186 /$ gb-spotlight-20030501-02 \\
\hline \hline ArticleCitationID & $:$ & spotlight-20030501-02 \\
\hline \hline ArticleSequenceNumber & $:$ & 116 \\
\hline \hline ArticleCategory & $:$ & Research news \\
\hline ArticleFirstPage & $:$ & 1 \\
\hline \hline ArticleLastPage & $:$ & 2 \\
\hline \hline & & RegistrationDate : 2003-5-1 \\
\hline ArticleHistory & $:$ & OnlineDate \\
\hline \hline ArticleCopyright & $:$ & BioMed Central Ltd2003-1 \\
\hline \hline ArticleGrants & $:$ & \\
\hline \hline ArticleContext & $:$ & 130594411 \\
\hline \hline
\end{tabular}




\section{Cathy Holding}

Email: cholding@hgmp.mrc.ac.uk

The use of anthrax spores as an agent of bioterrorism in 2001 led to a renewed interest in the fundamental biology and pathology of the bacterium Bacillus anthracis and to attempts to identify novel treatments for inhalation anthrax. In the May 1 Nature, two research articles report the use of wholegenome sequencing and comparative genomics of two Bacillus species: B. anthraci and B. cereus.

Timothy Read and colleagues at The Institute for Genomic Research in Rockville, USA, report the sequence of the genome of the lethal $B$. anthracis Ames strain and compare the predicted coding sequences with their own draft sequence of $B$. cereus (Nature 423:81-86, May 1, 2003). Natalia Ivanova and colleagues from Integrated Genomics, Chicago report the sequence of the genome of $B$. cereus and compare it with the B. anthracis sequence published last year by Read (Nature 423:87-91, May 1, 2003).

Ivanova et al. reported that 4505 coding sequences in B. cereus had $80-100 \%$ identity with their homologs in $B$. anthracis, suggesting a common ancestor. Fewer carbohydrate-catabolizing pathways were found than in $B$. subtilis, a soil bacterium, and more protein pathways, specifically for those in the intestine of insects, were found, suggesting the probable origin of the ancestral bacterium. Phenotypic differences were attributed to altered expression of predicted secreted proteins due to errors in the PclR positive regulator gene and to the acquisition of lethal toxin loci in one of the two plasmids in $B$. anthracis.

"All of this serves to underline the point that, whatever crude attempts are made by human beings, the true biowarfare experts are the bacteria themselves - they are constantly ready and exquisitely able to adapt to, and exploit, any environmental or pathogenic niche that presents itself," write Julian Parkhill from theWellcome Trust Sanger Institute, Cambridge, UK, and Colin Berry from Cardiff University, UK, in an accompanying News and Views article. "We can only hope that the availability of these sequences will assist those who are working to protect us against these agents of disease."

\section{References}

1. Inhalational anthrax and bioterrorism.

2. Nature, [http://www.nature.com]

3. The Institute for Genomic Research, [http://www.tigr.org]

4. Integrated Genomics, [http://www.integratedgenomics.com]

5. Wellcome Trust Sanger Institute, [http://www.sanger.ac.uk]

6. Cardiff University, [http://www.cardiff.ac.uk]

This PDF file was created after publication. 